\title{
PENGELOLAAN SUMBERDAYA PERIKANAN BERBASIS MASYARAKAT (PSPBM) MELALUI MODEL CO-MANAGEMENT PERIKANAN
}

\author{
A. Muluk Alains ${ }^{1}$ \\ Seprianti Eka Putri ${ }^{1}$ \\ Prilia Haliawan ${ }^{1}$ \\ ${ }^{1}$ Fakultas Ekonomi Universitas Bengkulu \\ E-mail: mulukalains@yahoo.co.id
}

\begin{abstract}
This study aims to identify the Co-Management PSPBM, on review of socio-economic dynamics and conflict management of traditional fishermen, in the city of Bengkulu. The nature of this study used qualitative methods-phenomenalogis with research sites in the city of Bengkulu. Data collection techniques include collecting secondary data and primary data through the determination of the informants, observation, depth interviews, FGDs. Results of research found a patron-client relationships are still very dominating this region, and once the economy of social security for fishermen. Kinship relations are generally good. Social solidarity is still high but not a guarantee, and survival strategies of fishermen are still relatively traditional sort because only starting point on the sea fishing only and does not extend to other areas that still use of marine resources. Results of analysis of conflict in general can be seen conflict among fishermen that happened in the three study sites are: class conflict, or vertical conflict and agrarian conflict.
\end{abstract}

Key word: co-management perikanan, konflik nelayan, patron-client, class conflict

\section{PENDAHULUAN}

Pengelolaan Sumberdaya Perikanan Berbasis Masyarakat (PSPBM) yang merupakan proses pemberian wewenang, tanggungjawab dan kesempatan kepada masyarakat untuk mengelola sumberdaya perikanannya sendiri telah menjadi populer pada saat ini. Namun rezim pengelolaan sumberdaya ini masih memiliki kelemahan yang bila tidak diselesaikan dapat membuat rezim ini tidak efektif pelaksanaannya. Beberapa kelemahan ini adalah bahwa PSPBM ini tidak mampu mengatasi masalah-masalah inter-komunitas, bersifat spesifik lokal, sangat rentan terhadap perubahan eksternal, sulit mencapai skala ekonomi, serta tingginya biaya institusionalisasinya.

Meskipun kerja sama merupakan sifat interaksi antara masyarakat, namun pengelolaan dan pemanfaatan sumberdaya perikanan cenderung makin berkurang, interaksi antara masyarakat lebih banyak terekspresi dalam bentuk saling kompetisi. Saling kompetisi dalam memanfaatkan sumberdaya ikan adalah alasan terjadinya kegagalan pengelolaan perikanan yang ditunjukkan dengan rusaknya 
sumberdaya serta adanya kemiskinan. Meskipun demikian, saling berinteraksi antara masyarakat dapat dipandang juga sebagai potensi yang dapat dikembangkan untuk merumuskan suatu mekanisme pengelolaan sumberdaya perikanan yang efektif. Keinginan masyarakat yang saling bertentangan atau berkompetisi merupakan salah satu alamiah masyarakat. Namun, sifat ini juga merupakan alasan perlunya dikembangkan mekanisme pengelolaan sumberdaya perikanan yang dapat mengatasi konflik. Mekanisme tersebut adalah dengan membiarkan masyarakat sendiri menentukan cara-cara pengelolaan sumberdaya perikanan yang ditujukan untuk mencapai tujuan yang juga ditetapkan mereka sendiri.

Terkait dengan hal tersebut, kota Bengkulu yang mempunyai luas wilayah $\pm 19.877,7 \mathrm{~km}^{2}$ dengan garis pantai yang membatasinya dengan Samudera Hindia sepanjang $525 \mathrm{~km}$ yang membentang ke arah laut lepas (ZEE 200mil) ini memiliki potensi besar yang belum tereksplorasi secara maksimal. Sementara itu banyak juga terdapat berbagai persoalan pengelolaan sumber daya perikanan tangkap di Bengkulu, yaitu terbatasnya modal dan akses ke sumber modal masih kurang, kualitas sumberdaya manusia masih rendah, sarana dan prasarana dan iklim usaha belum mendukung, konflik penggunaan ruang dan sumberdaya, pencurian ikan, penangkapan berlebih, luas wilayah penangkapan masih kurang (0-4mil), domisili nelayan masih tersebar di sepanjang pantai, konsentrasi dan bongkar muat tidak terkonsentrasi, sehingga pemanfaatan fungsi PPI dan TPI tidak optimal, rendahnya kemampuan manajemen pemasaran hasil perikanan, sehingga rendahnya tingkat margin yang diperoleh masyarakat nelayan walaupun harga jual ke konsumen akhir tinggi.

Berbagai masalah di atas tercermin pada tingkat kesejahteraan masyarakat yang hidup di sekitar wilayah pesisir masih rendah khususnya nelayan. Sebagian besar masyarakat hidup di bawah garis kemiskinan dengan kualitas sumberdaya manusia yang rendah. Untuk itu perlu kajian yang komprehensif tentang pengembangan sumberdaya yang ada di wilayah pesisir secara berkelanjutan untuk meningkatkan taraf hidup masyarakat di kawasan pesisir.

Arti dan logika PSPBM. PSPBM dapat didefinisikan sebagai suatu proses pemberian wewenang, tanggungjawab, dan kesempatan kepada masyarakat untuk mengelola sumberdaya perikanannya sendiri dengan terlebih dahulu mendefinisikan kebutuhan, keinginan, tujuan, serta aspirasinya. PSPBM menyangkut pula pemberian tanggungjawab kepada masyarakat sehingga mereka dapat mengambil keputusan yang pada akhirnya menentukan dan berpengaruh pada kesejahteraan hidup mereka. Masyarakat dalam definisi PSPBM ini adalah sekelompok orang yang memiliki tujuan yang sama. Istilah komunitas sendiri berasal dari bidang ilmu ekologi yang secara sederhana merujuk pada kondisi saling berinteraksi antara individu suatu populasi yang hidup dilokasi tertentu. Interaksi antara individu dalam suatu masyarakat pada dasarnya bersifat kompetitif. Meski demikian saling berinteraksi antara masyarakat dapat dipandang juga sebagai potensi yang dapat dikembangkan untuk merumuskan mekanisme pengelolaan sumberdaya perikanan tersebut.

Isu-Isu Strategis dalam Pengelolaan Sumberdaya Pesisir dan Laut. Semakin mencuatnya paradigma pembangunan kelautan serta dilaksanakannya otonomi daerah, maka 
semakin terbaca beberapa persoalan serius yang menjadi isu-isu strategis dalam pengelolaan sumberdaya pesisir dan laut ini, yaitu:

(1) Kondisi sumberdaya pesisir dan laut yang bersifat common property (milik bersama) dengan akses yang bersifat quasi open access, (2) Adanya degradasi lingkungan pesisir dan laut, (3) Kemiskinan dan kesejahteraan nelayan, (4) Akses pemanfaatan teknologi yang terbatas, (5) Peraturan dan kebijakan yang kurang kondusif.

Kerja Sama Pengelolaan Sumberdaya Pesisir dan Laut. Mengatasi berbagai permasalahan dan isu-isu yang mucul dalam pengelolaan sumberdaya pesisir dan laut ini, dibutuhkan suatu model pengelolaan yang kolaboratif yang memadukan antara unsur masyarakat pengguna (kelompok nelayan, pengusaha perikanan, dan lain-lain) dan pemerintah yang dikenal dengan Co-Management yang menghindari peran dominan yang berlebihan dari satu pihak dalam pengelolaan sumberdaya pesisir dan laut sehingga pembiasaan aspirasi pada satu pihak dapat dieliminasi. Melalui model ini, pengelolaan sumberdaya pesisir dan laut dilaksanakan dengan menyatukan lembaga-lembaga terkait terutama masyarakat dan pemerintah serta stakeholder lainnya dalam setiap proses pengelolaan sumberdaya, mulai dari perencanaan, pelaksanaan, pemanfaatan, dan pengawasan.

Pembagian tanggung jawab dan wewenang antar-stakehoder dapat terjadi dalam berbagai pola, tergantung kemampuan dan kesiapan sumberdaya manusia dan institusi yang ada di masing-masing daerah. Susunan dalam model pengelolaan ini bukanlah sebuah struktur legal yang statis terhadap hak dan aturan, melainkan sebuah proses yang dinamis dalam menciptakan sebuah struktur lembaga yang baru. Dalam jangka panjang, pelaksanaan Co-Management ini diyakini akan memberikan perubahan-perubahan ke arah yang lebih baik yaitu: (1) Meningkatkan kesadaran masyarakat akan pentingnya sumberdaya pesisir dan laut dalam menunjang kehidupan, (2) Meningkatkan kemampuan masyarakat, sehingga mampu berperan serta dalam setiap tahapan pengelolaan secara terpadu, (3) Meningkatkan pendapatan masyarakat dengan bentuk-bentuk pemanfaatan yang lestari dan berkelanjutan serta berwawasan lingkungan. Keberhasilan pengelolaan dengan model Co-Management ini sangat dipengaruhi oleh kemauan pemerintah untuk mendesentralisasikan tanggung jawab dan wewenang dalam pengelolaan kepada nelayan dan stakeholder lainnya. Oleh karena Co-Management membutuhkan dukungan secara legal maupun finansial seperti formulasi kebijakan yang mendukung ke arah $\mathrm{Co}$ Management, mengijinkan dan mendukung nelayan dan masyarakat pesisir untuk mengelola dan melakukan restrukturisasi peran para pelaku pengelolaan perikanan. Pengelolaan Co-Management menggabungkan antara pengelolaan sumberdaya yang sentralistis yang selama ini banyak dilakukan oleh pemerintah (government based management) dengan pengelolaan sumberdaya yang berbasis masyarakat (community based management).

Co-Management: Kolaborasi Pengelolaan Perikanan. Co-Management perikanan dapat didefinisikan sebagai pembagian atau pendistribusian tanggung jawab dan wewenang antara pemerintah dan masyarakat lokal dalam mengelola sumberdaya perikanan. Berdasarkan definisi ini maka pemerintah dan masyarakat bertanggungjawab bersamasama dalam melakukan seluruh tahapan pengelolaan perikanan. Apa yang menjadi 
tanggung jawab dan wewenang masingmasing pihak menentukan tipe atau bentuk Co-Management yang dianut. Definisi CoManagement ini juga menyiratkan bahwa kerjasama antarpemerintah dan masyarakat merupakan inti dari Co-Management.

Hirarki Co-Management Perikanan. Hirarki Co-Management muncul karena adanya berbagai kemungkinan proses pengambilan keputusan yang melibatkan masyarakat lokal dan pemerintah. Terdapat 3 hal yang menentukan variasi bentuk Co-Management serta hirarkinya yaitu: (1) Peranan pemerintah dan masyarakat dalam pengambilan keputusan; (2) Bentuk tugas dan fungsi manajemen yang dapat atau akan dikelola bersama oleh pemerintah dan masyarakat atau didistribusikan di antara kedua pihak; (3) Tahapan proses manajemen ketika secara aktual kerjasama pengelolaan betul-betul terwujud (sebagai contoh, pada tahapan perencanaan, implementasi atau evaluasi).

Selain hirarki Co-Management, Sen and Nielsen (1996) mengajukan hirarki yang lebih sederhana yang terdiri dari lima bentuk Co-Management. Kelima bentuk tersebut adalah (1) instruksi, (2) konsultasi, (3) koperasi, (4) pengarahan, dan (5) informasi.

Masyarakat dan Kebudayaan. Masyarakat yang menjadi kajian dalam rencana penelitian ini adalah masyarakat menurut Syani (2001) sebagai suatu Community yang dapat dilihat dari dua sudut pandang yaitu pertama sebagai unsur statis yang disebut masyarakat setempat (lokal) adalah suatu wadah dan wilayah dari kehidupan sekelompok orang yang ditandai oleh adanya hubungan sosial, dan dilengkapi dengan adanya perasaan sosial, nilai-nilai, dan norma-norma yang timbul atas akibat dari adanya pergaulan hidup atau hidup bersama manusia. Kedua, community sebagai unsur yang dinamis artinya menyangkut suatu proses yang terbentuk melalui faktor-faktor psikologis dan hubungan antarmanusia, di dalamnya terkandung unsur-unsur kepentingan, keinginan atau tujuan-tujuan yang sifatnya fungsional. Menurut Herkovits dan Malinoski, segala sesuatu yang terdapat dalam masyarakat ditentukan oleh adanya kebudayaan yang dimiliki oleh masyarakat itu (Soekanto, 1999). Konsep kebudayaan. Taylor (1871) didefinisikan sebagai keseluruhan yang kompleks meliputi pengetahuan, kepercayaan, kesenian, hukum, moral, adat istiadat dan berbagai kemampuan serta kebiasaan yang diperoleh manusia sebagai anggota masyarakat. (Soekanto, 1999).

Struktur Sosial. Menurut Lammer, struktur sosial adalah suatu jaringan abstrak yang mengatur hubungan dengan orang lain di dalam kehidupan masyarakat dalam suatu sistem tertentu. Selanjutnya, Van Doom \& Lammers menunjukkan bahwa struktur sosial suatu grup atau masyarakat dapat digambarkan dengan dua alternatif, yaitu: (1) alternatif pertama, sebagai jaring-jaring sejumlah "relasi sosial" dan "hubungan sosial" di dalam suatu pola atau kombinasi yang agak mantap unsur-unsurnya, seperti yang tergambar dari suatu "jarak sosial", suatu bentuk "integrasi" dan suatu jenis perbedaan "tingkatan" yang terdapat di antara pelaku-pelakunya dalam relasi dan hubungan sosial itu, (2) alternatif kedua, struktur sosial dapat pula dilihat sebagai kombinasi atau susunan sejumlah "posisi" sosial yang berhubungan dan saling mengisi.

Pola Kekerabatan. Pola kekerabatan sangatlah berbeda dengan struktur sosial yang ada di masyarakat. Menurut Sayogyo (2002) karena struktur kekerabatan menggambarkan pola hubungan berbeda daripada struktur 
kelompok-kelompok lain, yaitu karena adanya hubungan sosial berdasarkan hubungan sosial berdasarkan perkawinan dan berdasarkan hubungan darah, dimana berbagai pertimbangan perilaku orang-orang didalam kelompok itu tidak saja didasarkan atas pertimbangan biologis, namun juga atas dasar sosial.

Pola Interaksi Sosial. Pada hakikatnya Santosa (2000) manusia telah memiliki sifat yang dapat digolongkan ke dalam: manusia sebagai makhluk individual, manusia sebagai mahluk sosial dan manusia sebagai mahluk berketuhanan. Khususnya manusia sebagai mahluk sosial, maka sudah barang tentu hubungan sosial antara satu individu dengan individu lainnya merupakan suatu keharusan di samping tuntutan untuk hidup secara berkelompok.

Solidaritas Sosial. Menurut Durkheim, solidaritas sosial menunjuk pada suatu kesadaran hubungan antara satu individu dengan individu atau kelompok didasarkan pada perasaan dan kepercayaan yang dianut bersama yang diperkuat oleh pengalaman emosional bersama.

Konflik. Konflik berarti persepsi mengenai perbedaan kepentingan (perceived divergence of interest), atau suatu kepercayaan bahwa aspirasi pihak-pihak yang berkonflik tidak dapat dicapai secara simultan (Nikijuluw, 2000).

Penelitian ini bertujuan untuk menentukan pengelolaan sumberdaya pesisir terpadu berbasis masyarakat (PPSBM) melalui model Co-Management perikanan ditinjau dari dinamika sosial ekonomi dan manajemen konflik nelayan sesuai dengan kondisi lapangan yang terjadi di kota Bengkulu.

Secara rinci tujuan penelitian ini adalah sebagai berikut: (1) Menentukan model alternatif Co-Management PSPBM yang efektif bagi nelayan sehingga dalam upaya pemberian tanggungjawab kepada masyarakat dalam mengelola sumberdaya pesisir disesuaikan dengan kebutuhan serta kelangsungan hidup mereka sehari-hari. (2) Membuat perencanaan dan pengelolaan sumberdaya perikanan berbasis masyarakat melalui pengkajian sistematis tentang sumberdaya wilayah pesisir dan lautan serta potensinya, alternatif-alternatif pemanfaatannya serta kondisi ekonomi dan sosial untuk memilih dan mengadopsi cara-cara pemanfaatan pesisir yang paling baik untuk memenuhi kebutuhan masyarakat sekaligus mengamankan sumberdaya tersebut untuk masa depan. (3) Mengidentifikasi dinamika sosial ekonomi nelayan dan manajemen konflik nelayan tradisional di Bengkulu terutama mengenai batas-batas wilayah terdefinisi. (4) Menciptakan keterpaduan pengelolaan sumberdaya pesisir oleh para stakeholder, seperti keterpaduan visi dan misi dari pengelolaan yang dilakukan.

Urgensi (Keutamaan) Penelitian. Pengelolaan sumber daya wilayah pesisir dan kelautan, khususnya sumberdaya perikanan berbasis masyarakat sekarang menjadi tuntutan di era otonomi daerah, menjadikan harapan dan sekaligus membuka permasalahan baru seiring dengan adanya pemberian wewenang kepada daerah untuk mengelola dan memanfaatkan sumberdaya ini, yang diharapkan manfaat terbesar akan berpindah dari pemerintah pusat ke pemerintah daerah terutama masyarakatnya. Namun permasalahan yang dihadapi sekarang adalah seberapa besar keinginan dan komitmen pemerintah daerah untuk mengelola sumberdaya di wilayahnya secara berkelanjutan. Pertanyaan ini 
penting, mengingat tidak seluruh daerah memiliki pemahaman yang sama akan arti pentingnya pengelolaan sumberdaya kelautan secara berkelanjutan. Pembangunan secara berkelanjutan pada dasarnya adalah pembangunan untuk mencapai "keseimbangan" antara manfaat dan kelestariannya sumberdaya pesisir dan lautan. Artinya, bahwa sumberdaya ini dapat dieksploitasi untuk kemaslahatan manusia namun tidak menjadikan lingkungan termasuk sumberdaya itu menjadi rusak. Berdasarkan analisis situasi yang ada di kota Bengkulu selama ini program kebijakan pemerintah tidak sesuai dengan kebutuhan nelayan sebagai contoh dalam perencanaan program percepatan pembangunan sektor kelautan dan perikanan Kota Bengkulu kurang memperhatikan kapasitas SDM nelayan (fisherman), sebagai contoh: adanya pemberian bantuan alat tangkap yang bersifat moderen kepada nelayan, namun di satu sisi nelayan tidak bisa menggunakannya, perlu dilatih terlebih dahulu. Sehingga dapat dikatakan program pemerintah masih bersifat top down, maka untuk perlu adanya keselarasan dari kedua belah pihak antara nelayan sebagai pemegang kepentingan dan pemerintah sebagai pembuat kebijakan. Melalui Co-Management perikanan inilah yang bisa menjembatani untuk mewujudkan proses pengambilan keputusan di antara keduabelah pihak sehingga menjadi mekanisme untuk mencapai visi dan tujuan nelayan lokal serta mengurangi konflik antarnelayan melalui proses yang partisipatif.

\section{METODE PENELITIAN}

\section{Sifat Penelitian}

Penelitian ini menggunakan metode kualitatif-phenomenalogis yaitu prosedur penelitian yang menghasilkan data deskriptif berdasarkan fenomena yang diteliti.

\section{Lokasi Penelitian}

Penelitian dilakukan pada masyarakat nelayan di tiga kelurahan yaitu kelurahan Pasar Bengkulu kecamatan Sungai Serut, Kelurahan Malabero kecamatan Teluk Segara, dan Tempat Pelelangan Ikan (TPI) Pulau Baai kota Bengkulu, yang termasuk kedalam lingkungan kelurahan Sumber Jaya kecamatan Kampung Melayu kota Bengkulu. Pemilihan lokasi ini ditetapkan berdasarkan beberapa pertimbangan yaitu memiliki sumber daya alam pesisir dan laut yang cukup potensial terutama perikanan laut/perikanan tangkap, dan lokasi tersebut merupakan tempat pendaratan/pelabuhan perikanan tangkap dan memiliki sarana TPI yang representatif dan merupakan lokasi dimana nelayan tradisional sering terlibat konflik penggunaan ruang dan sumberdaya. Penelitian ini dilaksanakan selama 9 bulan dengan mengambil sampel nelayan tradisional dan nelayan moderen yang tersebar di ketiga lokasi penelitian.

\section{Teknik Pengumpulan Data}

Pengumpulan Data Sekunder. Dilakukan dengan studi pustaka dokumenter dengan inventarisasi informasi dari buku-buku, laporan penelitian, prosiding dokumen/bahan laporan dari Dinas Kelautan dan Perikanan, BPS, Profil Kabupaten, Peraturan Perundang-undangan, dan bahan lain yang menunjang dan berkaitan dengan materi penelitian.

Pengumpulan Data Primer. (a) Metode Participatory Rural Appraisal atau PRA (Chambers, 1992), yaitu (FGD). Teknik FGD ini digunakan terutama untuk memperoleh informasi dari berbagai sumber dalam satu media diskusi yang terfokus. Para peser- 
pengembangan keterampilan yang tidak hanya terpaku pada bidang kelautan saja seperti melaut, mengasinkan ikan. Namun dapat memungkinkan untuk lebih luas lagi seperti sektor jasa atau sektor lainnya yang masih berkaitan dengan dunia kelautan. Seperti nelayan Bugis yang berada di daerah Kampung Melayu yang terkenal dengan keterampilan yang dimiliki untuk membuat perahu dan kapal yang lebih baik mutunya atau membuat lembaga yang secara khusus mengajarkan cara-cara pembuatan perahu dan kapal.

Pemerintah hendaknya dapat mengakomodir kebutuhan masyarakat nelayan, karena secara umum bantuan dari pemerintah terkadang tidak tepat sasaran, hal ini disebabkan pemerintah relatif tidak melihat kebutuhan nelayan di lapangan sehingga banyak bantuan yang sifatnya mubazir. Diharapkan melalui skenario Co-Management ini pemerintah dan masyarakat sebagai mitra sejajar dapat bekerjasama untuk melaksanakan semua tahapan dan tugas proses pengelolaan sumberdaya perikanan.

\section{DAFTAR PUSTAKA}

Arif Satria, dkk. 2002. Menuju Desentralisasi Kelautan. Kerjasama Pusat Kajian Agraria IPB, Partnership for Governance Reform in Indonesia dan PT Pustaka Cidesindo. Jakarta.

Arwani dkk. 1998. Strategi Keberlangsungan Ekonomi Petani Miskin Berekosistem Lahan Kering dan Persawahan: Studi Kasus di Kabupaten Bengkulu Utara. Laporan Penelitian UNIB.

Ahmed, et all. 1995. Fisheries Co-Management in Bangladesh. Experience with GO-NGO. Fisheries Partnership Mod- els. Presented at the Fifth Conference of The International Association for The Study of Common Property. Bodo. Norway.

Bactiar dkk. 2002. Identifikasi Isu Permasalahan Dalam Rangka Pengelolaan Kawasan Pesisir Secara Terpadu Bengkulu. Makalah disampaikan pada Seminar Nasional dalam rangka Dies Natalies dan Lustrum UNIB.

BPS.2009. Data Statistik.Bengkulu.

Chamber, Robert, 1992. Rural Appraisal: Rapid Relaxed and Participatory: England: Institute of Development Studies.

Dahuri, R. 2000. Pendayagunaan Sumberdaya Kelautan untuk Kesejahteraan Rakyat (Kumpulan Pemikiran). Kerja sama LISPI dengan Ditjen P3K, DKP. Jakarta.

Dinas Kelautan \& Perikanan, 2006. Laporan Tahunan. Kota Bengkulu.

Doyle P. Jhonson. 1986. Teori Sosiologi Klasik dan Modern. (Diterjemahkan oleh Robert M.Z. Lawang, Jilid kedua) PT. Gramedia Pustaka Utama: Jakarta.

Hanna, S. 1992. Creating User Group Vested in Fishery Management Outcomes. A Case Study of The Pacific Fishery Management Council. Presented at The Word Fisheries Congress, Athens, Greece.

Kusnadi, 2002. Konflik Sosial Nelayan, Kemiskinan dan Perebutan Sumberdaya Perikanan, Yogyakarta.

Kanous, William, 2003. Lakukan Segera. Motivasi Dasar untuk Menumbuhkan Semangat Bekerja dan Bertindak. Semarang: Dahara Prize.

Kartika, Titiek. 1993. Identifikasi Sosial Bu- 
daya Masyarakat Suku Serawai. Laporan Penelitian. Lembaga Penelitian UNIB.

Moleong, 2002. Metode Penelitian Kualitatif. Edisi ke-7. Bandung: PT. Remaja Rosda Karya.

Mubyarto;Loekman Sutrisno;Michael Dove, 1984. Nelayan dan Kemiskinan, Jakarta: Rajawali Press.

Nikijuluw, V.P.H. 2000. Rezim Pengelolaan Sumberdaya Perikanan. Jakarta: P3R dan PT Pustaka Cidesindo.

Nugroho, Sumarno.2002.Sistem Interpensi Kesejahteraan. Yogyakarta: Hanindita.

Purnomowati, R. 2003. Menuju Pengelolaan Sumberdaya Pesisir Terpadu Berbasis Masyarakat. Makalah disampaikan pada Pelatihan ICZPM. Kerjasama PKSPL-IPB dengan Ditjen P3K, DKP. Bogor

Pomery and Pido. 1995. Intiatives Forward Fisheries Co-Management A Multi Disciplinary Assesment. Vancouver: University of British Columbia Press.

Pemerintah Daerah Kota Bengkulu, Kantor PMD. 2009. Profil Kelurahan Kota
Bengkulu.

Sajogyo, 2002. Sosiologi Pembangunan. Fakultas Pascasarjana IKIP Jakarta kerja sama BKKBN. Jakarta.

Shadily, 1984. Sosiologi untuk Masyarakat Indonesia. Jakarta: PT. Bina Aksara.

Sastrawijaya; Mandianto, 2002. Nelayan Nusantara. Jakarta: Pusat Riset Pengolahan Produk dan Sosek Kelautan dan Perikanan Badan Riset Kelautan dan Perikanan.

Soekanto, Soejono. 1999. Pokok-Pokok Sosiologi Hukum, Jakarta: Rajawali.

Syani, Abdul. 2001. Sosiologi Kelompok dan Masalah Sosial. Yogyakarta: Fajar Agung.

Santoso, Slamet. 2000. Dinamika Kelompok. Jakarta: Bumi Aksara.

Tarigan, Jarto. 1995. Dampak Interaksi Kelembagaan Adat dan Pemerintah Desa di provinsi Bengkulu. Laporan Penelitian. Lembaga Penelitian Unib.

Topan, Asep.1995. Partisipasi Masyarakat Nelayan dalam Pengelolaan Lingkungan Pantai dan Laut di Kota Bengkulu. 


\title{
PEDOMAN PENULISAN \\ JURNAL EKONOMI PEMBANGUNAN FAKULTAS EKONOMI UNIVERSITAS MUHAMMADIYAH SURAKARTA
}

Terbit: 2 kali dalam setahun pada bulan Juni dan Desember

\author{
Akreditasi Jurnal: \\ KEPUTUSAN DIREKTUR JENDERAL PENDIDIKAN TINGGI \\ KEMENTERIAN PENDIDIKAN NASIONAL NOMOR: 51/DIKTI/Kep./2010 \\ (masa berlaku Juni 2010 s.d Juni 2013)
}

1. Artikel ditulis dengan bahasa Indonesia atau bahasa Inggris dalam bidang kajian masalah ekonomi dan pembangunan.

2. Substansi artikel diharapkan sejalan dengan Panduan Akreditasi Berkala Ilmiah 2006, yang diterbitkan Direktorat Penelitian dan Pengabdian kepada Masyarakat (DP2M) Direktorat Jenderal Pendidikan Tinggi Republik Indonesia).

3. Artikel ditulis dengan kaidah tata bahasa Inggris ataupun bahasa Indonesia yang baik dan benar.

4. Sistematika Penulisan

Sistematika penjenjangan atau peringkat judul artikel dan bagian-bagiannya dilakukan dengan cara berikut:

(1) Judul ditulis dengan huruf besar semua, di bagian tengah atas pada halaman pertama

(2) Sub Bab Peringkat 1 ditulis dengan huruf pertama besar semua di tengah/center

(3) Sub Bab Peringkat 2 ditulis dengan huruf besar-kecil rata tepi kiri

- Sistematika artikel hasil penelitian adalah: judul; nama penulis (tanpa gelar akademik); nama dan alamat institusi, alamat e-mail penulis, abstrak (maksimum 150 kata) yang berisi tujuan, metode, dan hasil penelitian; kata kunci (4-5 kata kunci); pendahuluan (tanpa ada subjudul) yang berisi latar belakang, sedikit tinjauan pustaka, dan tujuan penelitian; metode; hasil penelitian dan pembahasan; kesimpulan; daftar rujukan (hanya memuat sumber-sumber yang dirujuk).

\section{JUDUL UTAMA:}

\section{Sub Judul}

Penulis $1^{1}$ dan Penulis $2^{2}$

${ }^{1}$ Nama instansi/lembaga Penulis 1

Alamat lengkap instansi penulis, nomor telepon instansi penulis

${ }^{2}$ Nama instansi/lembaga Penulis 2

Alamat lengkap instansi penulis, nomor telepon instansi penulis

(jika nama instansi penulis 1 dan 2 sama, cukup ditulis satu saja)

E-mail penulis 1 dan 2:

Abstrak: Abstrak dalam bahasa Indonesia (125 - 150 kata)

Kata kunci: 4 - 5 katal frase

Abstract: Abstract in english (125 - 150 words)

Keywords: $4-5$ words/ phrase

\section{PENDAHULUAN}

(berisi latar belakang, sekilas tinjauan pustaka, dan tujuan penelitian, yang dimasukkan dalam paragraf paragraf bukan dalam bentuk subbab)

METODE PENELITIAN

Subbab

Subbab

...

\section{HASIL ANALISIS DAN PEMBAHASAN}

Pedoman Penulisan Jurnal Ekonomi Pembangunan FE Universitas Muhammadiyah Surakarta 


\title{
Subbab
}

\section{KESIMPULAN \\ DAFTAR PUSTAKA}

- Sistematika artikel hasil pemikiran adalah: judul; nama penulis (tanpa gelar akademik); nama dan alamat institusi, alamat e-mail penulis, abstrak (maksimum 150 kata); kata-kata kunci (4-5 kata kunci); pendahuluan (tanpa ada subjudul) yang berisi latar belakang dan tujuan atau ruang lingkup tulisan; bahasan utama (dapat dibagi ke dalam beberapa sub-judul); penutup atau kesimpulan; daftar rujukan (hanya memuat sumber-sumber yang dirujuk).

\section{JUDUL UTAMA: \\ Sub Judul}

Penulis $1^{1}$ dan Penulis $2^{2}$

${ }^{1}$ Nama instansi/lembaga Penulis 1

Alamat lengkap instansi penulis, nomor telepon instansi penulis

${ }^{2}$ Nama instansi/lembaga Penulis 2

Alamat lengkap instansi penulis, nomor telepon instansi penulis

(jika nama instansi penulis 1 dan 2 sama, cukup ditulis satu saja)

E-mail penulis 1 dan 2 :

\author{
Abstrak: Abstrak dalam bahasa Indonesia (125--150 kata) \\ Kata kunci: 4 - 5 katal frase \\ Abstract: Abstract in english (125 - 150 words) \\ Keywords: $4-5$ words/ phrase

\section{PENDAHULUAN PEMBAHASAN \\ KESIMPULAN} \\ DAFTAR PUSTAKA
}

5. Artikel diketik pada kertas kwarto berkualitas baik. Dibuat sesingkat mungkin sesuai dengan subyek dan metode penelitian (bila naskah tersebut ringkasan penelitian), biasanya 20-25 halaman dengan spasi satu, untuk kutipan paragraf langsung diindent (tidak termasuk daftar pustaka).

6. Marjin atas, bawah, dan samping harus dibuat paling tidak satu inci.

7. Abstrak, ditulis satu paragraf sebelum isi naskah. Abstrak dalam dua bahasa yaitu bahasa Indonesia dan bahasa Inggris. Abstrak tidak memuat uraian matematis, dan mencakup esensi utuh penelitian, metode dan pentingnya temuan dan saran atau kontribusi penelitian.

8. $\quad$ a. Penulisan numbering diintegrasikan dalam paragraf, contohnya:

Tujuan dilakukannya penelitian ini adalah: (1) Untuk mengetahui apakah CSR berpengaruh positif terhadap nilai perusahaan, (2) Untuk mengetahui apakah persentase kepemilikan manajemen berperan sebagai variabel moderating dalam hubungan antara CSR dengan nilai perusahaan, dan (3) Untuk mengetahui apakah tipe industri berperan sebagai variabel moderating dalam hubungan antara CSR dengan nilai perusahaan?

b. Penulisan bullet juga diintegrasikan dalam paragraf dengan menggunakan tanda koma pada antarkata/kalimat tanpa bullet.

9. Tabel dan gambar, untuk tabel dan gambar (grafik) sebagai lampiran dicantumkan pada halaman sesudah teks. Sedangkan tabel atau gambar baik di dalam naskah maupun bukan harus diberi nomor urut.

- Tabel atau gambar harus disertai judul. Judul tabel diletakkan di atas tabel sedangkan judul gambar diletakkan di bawah gambar.

Pedoman Penulisan Jurnal Ekonomi Pembangunan FE Universitas Muhammadiyah Surakarta 
- Sumber acuan tabel atau gambar dicantumkan di bawah tabel atau gambar.

- Garis tabel yang dimunculkan hanya pada bagian header dan garis bagian paling bawah tabel sedangkan untuk garis-garis vertikal pemisah kolom tidak dimunculkan.

Contoh: Tabel

Tabel 1. Bentuk-bentuk Mobilitas Penduduk

\begin{tabular}{llll}
\hline No & Bentuk Mobilitas & Batas Wilayah & Batas Waktu \\
\hline 1. & Ulang-alik (commuting) & Dukuh (dusun) & 6 jam atau lebih dan kembali pada hari yang sama \\
2. & Menginap/mondok di daerah tujuan & Dukuh (dusun) & Lebih dari satu hari tetapi kurang dari 6 bulan \\
3. & Permanen/menetap di daerah tujuan & Dukuh (dusun) & 6 bulan atau lebih menetap di daerah tujuan \\
\hline
\end{tabular}

Sumber: Ida Bagoes, 2000

\section{Contoh: Gambar}

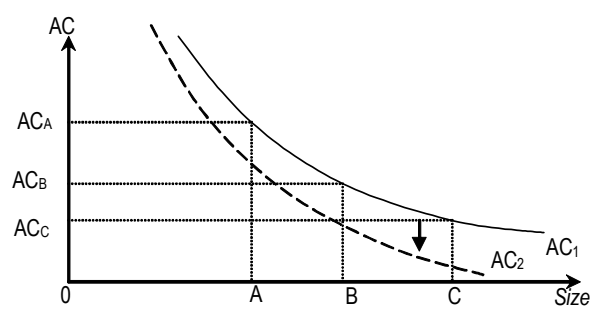

Sumber: Saunders (1997: 291)

Gambar 2. Dampak Peningkatan Teknologi

10. Cara penulisan rumus, Persamaan-persamaan yang digunakan disusun pada baris terpisah dan diberi nomor secara berurutan dalam parentheses (justify) dan diletakkan pada margin kanan sejajar dengan baris tersebut. Contoh:

$\mathrm{wt}=\mathrm{f}\left(\mathrm{y}_{\mathrm{t}}, \mathrm{k}_{\mathrm{t}}, \mathrm{w}_{\mathrm{t}-1}\right)$

11. Keterangan Rumus ditulis dalam satu paragraf tanpa menggunakan simbol sama dengan (=), masingmasing keterangan notasi rumus dipisahkan dengan koma. Contoh:

Dimana $\mathbf{w}$ adalah upah nominal, $\mathbf{y t}$ adalah produktivitas pekerja, kt adalah intensitas modal, $\mathbf{w}_{\mathbf{t}-\mathbf{1}}$ adalah tingkat upah periode sebelumnya.

12. Perujukan sumber acuan di dalam teks dengan menggunakan nama akhir dan tahun. Kemudian bila merujuk pada halaman tertentu, penyebutan halaman setelah penyebutan tahun dengan dipisah titik dua. Untuk karya terjemahan dilakukan dengan cara menyebutkan nama pengarang aslinya.

Contoh:

- Yuni (2008: 23) memandang bahwa .....

- Fatimah dan Daryono (1997) menunjukkan adanya ....

- Didit dkk (2007) berkesimpulan bahwa....

- Untuk meningkatkan perekonomi daerah .... (Yuni, Triyono, dan Agung Riyardi, 2009).

- Maya (2009) berpendapat bahwa ....

13. Setiap kutipan, baik langsung maupun tidak langsung, harus diikuti sumbernya (lihat poin no. 10) dan dicantumkan juga dalam daftar pustaka. Contoh:

Di dalam paragraf isi tercantum kutipan dari: Buiter (2007:15) berpendapat bahwa...

Maka dalam daftar pustaka harus ada sumber referensinya seperti berikut:

Buiter, W. H., (2002). The Fiscal Theory of the Price Level: A Critique, Economic Journal, 112(127): 459-480.

Pedoman Penulisan Jurnal Ekonomi Pembangunan FE Universitas Muhammadiyah Surakarta 
14. Sedapat mungkin pustaka-pustaka yang dijadikan rujukan adalah pustaka yang diterbitkan 10 tahun terakhir dan diutamakan dari jurnal ilmiah.

15. Unsur yang ditulis dalam daftar pustaka secara berturut-turut meliputi: (1) nama akhir pengarang, nama awal, nama tengah, tanpa gelar akademik, (2) tahun penerbitan, (3) judul termasuk subjudul, (4) tempat penerbitan, (5) nama penerbit.

Contoh cara penulisan:

a. Format rujukan dari buku: Nama pengarang, (tahun), Judul Buku, edisi, Kota penerbit, Nama penerbit. Jika penulis sebagai editor tunggal, ditulis (Ed.) di belakang namanya. Ditulis (Eds.) jika editornya lebih dari satu orang. Kemudian bila pengarang lebih dari tiga orang, dituliskan nama pengarang pertama dan yang lain disingkat 'dkk' (pengarang domestik) atau 'et.al.' (pengarang asing).

Enders, W., (2004), Applied Econometric Time Series, Second edition, New York: John Wiley \& Sony Inc. Purnomo, Didit (Ed.). (2005). The Role of Macroeconomic Factors in Growth. Surakarta: Penerbit Muhamadiyah University Press.

b. Format rujukan dari artikel dalam buku ditulis: Nama editor (Ed.), (tahun), Judul tulisan/karangan. Judul buku, hlm atau pp., kota penerbit: nama penerbit

Daryono (Ed.). (2005). Concept of Fiscal Decentralization and Worldwide Overview (hlm. 12-25). Surakarta: Penerbit Muhammadiyah University Press.

c. Format rujukan dari artikel dalam jurnal/majalah/koran: Nama pengarang (tahun). judul tulisan/ karangan. Nama jurnal/majalah/koran, hlm atau pp., volume (nomor), halaman. Jika rujukan koran tanpa penulis, nama koran ditulis diawal.

Rodden, J., (2002). The dilemma of Fiscal Federalism: Grants and Fiscal Performance arround the World. American Journal of Political Science, 46 (3): 670-687.

Triyono (2008). Perimbangan Keuangan Pusat dan Daerah Sebagai Pelaksanaan Desentralisasi Fiskal Efek. Warta Ekonomi, Vol. 4, Agustus: 46-48.

Haryanto, S., (2007, 13 November). Desentralisasi Fiskal dan Pembangunan Ekonomi. Harian Jakarta, hlm.4.

Harian Jogjakarta, (2007, 1 April). Hubungan Keuangan Pusat-Daerah di Indonesia. hlm. 4.

d. Format rujukan dari internet, tanggal akses dicantumkan.

Setyowati, E.,. Keuangan Publik dan Sistem Harga. http://www.ekonomipublik.com/akt/pdf/akt452.pdf.

Diakses tanggal 27 Mei 2009.

\section{Pengiriman Artikel}

1. Artikel dikirimkan sebanyak 2 eksemplar hardcopy, dan softcopy berupa file. File bisa dikirim melalui email jepums@yahoo.co.id atau dalam media cd.

2. Artikel yang dikirim wajib dilampiri biodata ringkas pendidikan termasuk catatan riwayat karya-karya ilmiah sebelumnya yang pernah dipublikasikan, insitusi dan alamatnya, nomor telpon kontak atau e-mail penulis.

3. Penulis yang menyerahkan artikelnya kepada editor atau penerbit, harus menjamin bahwa naskah yang diajukan tidak melanggar hak cipta, belum dipublikasikan atau telah diterima untuk dipublikasi oleh jurnal lainnya.

4. Kepastian pemuatan atau penolakan naskah akan diberitahukan secara tertulis. Penulis yang artikelnya dimuat mendapatkan jurnal tersebut. Artikel yang tidak dimuat tidak akan dikembalikan.

\section{Alamat Redaksi Jurnal Ekonomi Pembangunan Fakultas Ekonomi Universitas Muhammadiyah Surakarta: \\ Redaksi Jurnal Ekonomi Pembangunan Fakultas Ekonomi Universitas Muhammadiyah Surakarta Jalan A. Yani Tromol Pos I Pabelan SURAKARTA 57102 Telp. 0271-717417 psw 229}

Pedoman Penulisan Jurnal Ekonomi Pembangunan FE Universitas Muhammadiyah Surakarta 
TENTANG JURNAL:

\title{
JURNAL EKONOMI PEMBANGUNAN
}

Kajian Masalah Ekonomi dan Pembangunan

ISSN 1411- 6081

\author{
Pimpinan Redaksi \\ Didit Purnomo
}



Jurnal EKONOMI PEMBANGUNAN merupakan jurnal ilmiah yang berisikan hasil penelitian dan kajian teoritis mengenai masalah-masalah ekonomi dan pembangunan, khususnya di Indonesia. Diterbitkan oleh Balai Penelitian dan Pengembangan Ekonomi Fakultas Ekonomi Universitas Muhammadiyah Surakarta.

Redaksi menerima sumbangan tulisan yang belum pernah diterbitkan atau dalam proses terbit oleh media lain. Naskah diketik di atas kertas HVS kuarto spasi satu sepanjang lebih kurang 20-25 halaman, dengan format seperti tercantum pada prasyarat naskah jurnal EKONOMI PEMBANGUNAN di halaman belakang. Naskah yang masuk akan dievaluasi dan disunting untuk keseragaman format dan tata cara lainnya.

Alamat Penyunting dan Tata Usaha: Subag Tata Usaha Fakultas Ekonomi Universitas Muhammadiyah Surakarta, Jl. A. Yani, Tromol Pos 1, Pabelan, Surakarta 57102; Telpon (0271) 717417 psw 229,

E-mail: jepums@yahoo.co.id

Website: http://www.ums.ac.id atau http://www.paradejurnal.wordpress.com

Simak informasi jurnal: http://www.paradejurnal.wordpress.com

Admin: Mirat Sidharta. SE

Pedoman Penulisan Jurnal Ekonomi Pembangunan FE Universitas Muhammadiyah Surakarta 